\title{
Some aquatic Hyphomycetes on grasses in Finland
}

\author{
Kaiho Mäkelä
}

\author{
Department of Plant Pathology, University of Helsinki, Viikki, 00710 Helsinki 71, Finland
}

\begin{abstract}
This paper is part of a larger study of the fungi causing leaf-spot diseases on the grasses in leys in Finland. The material examined consisted of grasses growing on cultivated grassland or in the borders of fields. The fresh material (c. 3770 samples) was collected throughout the country, but chiefly from the Viikki Experiment Farm of Helsinki University, from 1966 to 1970 . Conidia produced in natural infestations were examined microscopically. The fungi have not been grown in pure culture.

Conidia of the fungi were found on the growing leaves of grasses during the period between early spring (March) and late autumn (November). They occurred rather commonly but in small numbers; mostly only single spores of fungi were found. The aquatic Hyphomycetes live as saprophytic fungi on grasses, and are of negligible importance.

Four species of the aquatic Hyphomycetes were identified on 14 grass species. The most common species was Volucrispora graminea (Haskins) Ingold, McDougall \& Dann. Tricellula aquatica Webster occurred rather commonly, but in small numbers. Varicosporium elodeae Kegel was found on two samples of Phleum pratense L. and Tetracladium maxilliformis (Rostrup) Ingold on one of Dactylis glomerata L.
\end{abstract}

\section{Introduction}

Mycologists have investigated the aquatic Hyphomycetes during the last three decades. Material for study has been collected mostly from decaying leaves of trees and shrubs (e.g. Alnus, Quercus, Castanea, Salix, Populus, Betula, Cornus, Rubus) and other plant debris or from scum and foam from streams, lakes and other waters (INGoLd 1942, 1943, 1944, Ingold \& Ellis 1952, Fenton 1950, Webster 1959, Baxter 1960, Peterson 1962a, NiLsson 1964). Material from terrestrial plants growing in fields (Rostrup 1894, InGold et al. 1968) and from soil (Bessey 1939, WaID 1954, Nilsson 1964, Doмsch \& Gams 1970) has been collected rarely. The demarcation line between the aquatic members and the terrestrial members of Hyphomycetes is not distinct (cf. Tubaki 1957, NiLsson 1964). Many fresh water Hyphomycetes e.g. Tetracladium maxilliformis and Varicosporium elodeae occur in different types of habitats from terrestrial to semiaquatic in addition to streams and lakes (Nilsson 1964).

The climatic conditions may be of major importance for the survival of some aquatic Hyphomycetes, but for the majority of the common species they are not (Nilsson 1964). However, a relatively low temperature optimum is a frequent feature of aquatic $\mathrm{Hypho-}$ mycetes from Britain (INGOLD 1944, THORNTON 1963).

The purpose of the present paper is to report the occurrence of some aquatic $\mathrm{Hypho-}$ mycetes on leaves of grasses. The material examined consisted of grasses growing on cultivated leys or in borders of fields. This paper is part of a larger study of fungi causing leaf spot diseases (cf. MäkELÄ 1972).

\section{Materials and Methods}

Grass samples were collected between spring thaw and the first heavy snow fall in 


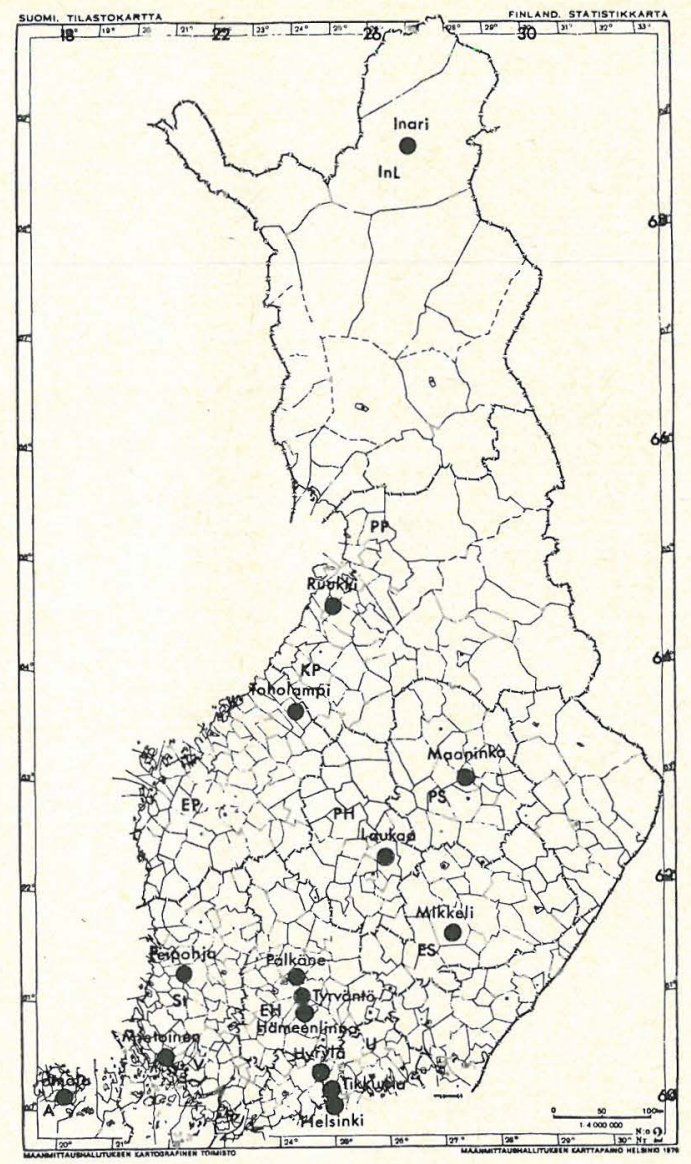

Fig. 1. Origin of the material.

autumn during the years 1966-1970. Approximately 3770 samples in all were collected from leys and field borders at Viikki, the Muddusniemi Experiment Farm of Helsinki University, Experiment Stations of the Agricultural Research Centre, The Plant Breeding Institute of Hankkija in Hyrylä, at Hämeenlinna, and from fields in the vicinity of $\mathrm{Hel}$ sinki (Fig. 1).

Conidia produced in natural infestations were examined. The slides of the fungus material were prepared from fresh grass leaves and placed on slides in lactic-acid and lactophenol solutions with trypanblue where the conidia were measured and photographed. The fungi were not grown in pure culture.

\section{Results and Discussion}

Volucrispora Haskins, Canad. J. Microbiol. 4: 278, 1958.
Volucrispora graminea (Haskins) Ingold, McDougall \& Dann, Trans. Brit. Mycol. Soc. 5: 325--328, 1968. Similar spores were described by de Wildeman (1893), Ingold (1942), Webster (1954) and Nilsson (1962, 1964). Webster's (1954) isolates were from Dactylis glomerata and apparently also from Poa. As a rule, spores this type have been isolated from fresh water.

In the present study the fungus was found on 360 grass samples involving 12 grass species and from different localities ranging from Helsinki to Lapland (at Inari). Spores of the fungus were found during the period between early spring (28. III. 1968), often immediately after the spring thaw, and late autumn (24. XI. 1967). Conidia were most abundant in the spring months, i.e. from April to May, and also in autumn, whereas midsummer occurrence was infrequent. According to INGOLD et al. (1968) the temperature optimum for growth of this fungus in $2 \%$ malt solution was in the $15-20^{\circ} \mathrm{C}$ range with no growth at $25^{\circ} \mathrm{C}$. Also in INGoLD's studies $(1942,1944)$ most species of aquatic Hyphomycetes reached their best development in autumn and winter.

In the present study conidia of Volucrispora graminea were observed in less than $10 \%$ of the 3770 samples examined. The fungus was found most at Viikki (Helsinki).

The hyaline conidia (about 570 examined) consist of a slightly curved main axis averaging (18) 32 (60) $\mu$ long, (1.5) 2.7 (4.4) $\mu$ wide, (2) 2 (7) -septa, and a smaller single lateral branch $0-1$-septa. Sometimes the branch fails to form (Fig. 2 A, G, G, L, Q) (cf. Ingold et al. 1968). The distance between the tips of the two branches in the conidium was (12) 20 (39) $\mu$. In the present study the spores were larger than those described by INGOLD et al. (1968) in which the main axis was $1-3$-septate, 25-40 $\mu$ long, and $1.5-2 \mu$ broad, and lateral branches 10 -20 $\mu$ long and $1.5 \mu$ broad, 0 - 1-septate. On the other hand the form of conidia was similar in both studies (Figs. 2, 3) (cf. also Haskins 1958).

The form and size of the conidia from different localities, grasses and times of collection showed little variation (Figs. 2, 3).

Material examined

On Agropyron repens (L.) PB.:

U: Helsinki, Viikki (2 specimens); ES: Mikkeli (1 specimen). 


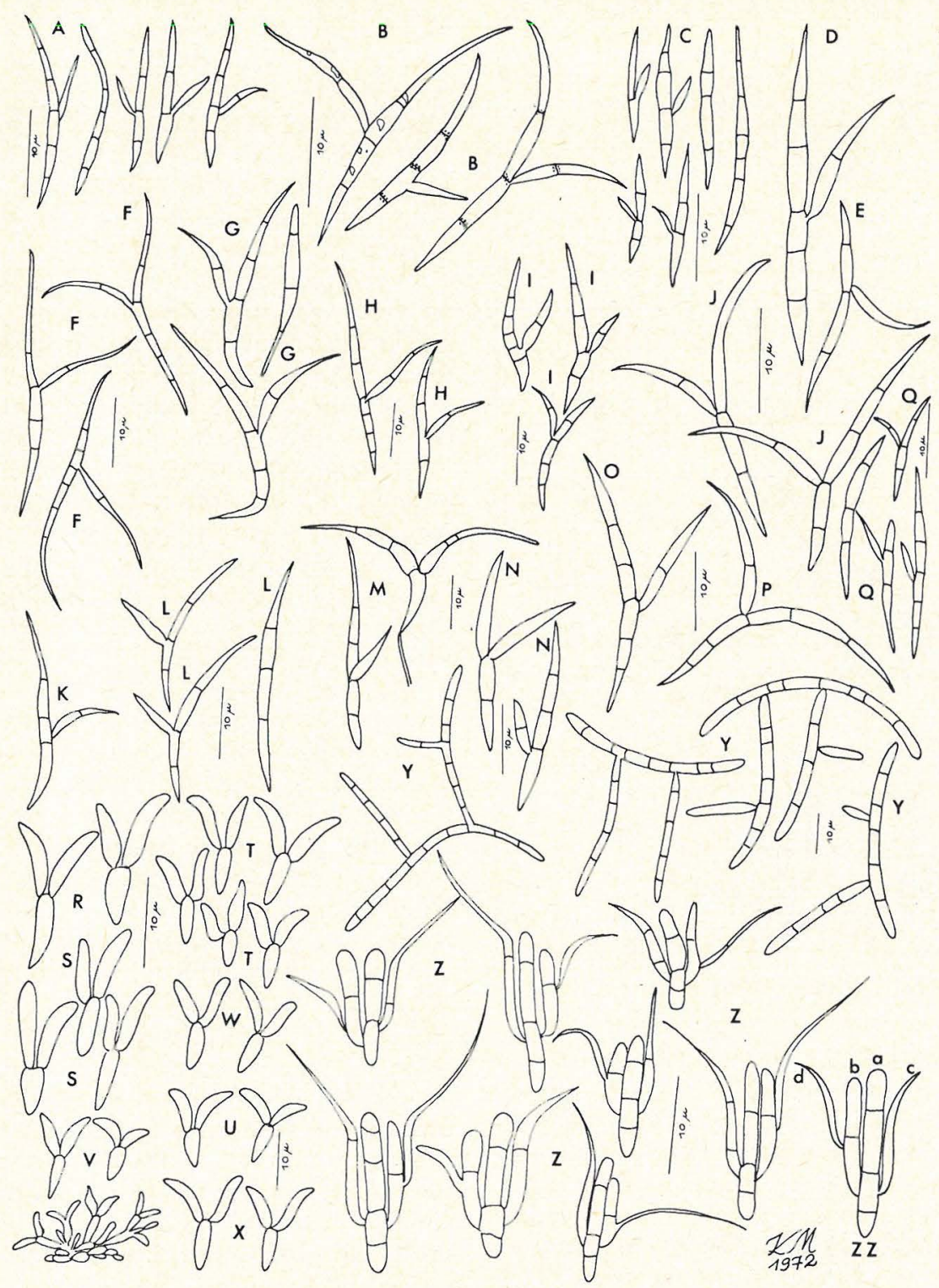

Fig. '2. Conidia of Volucrispora graminea A-Q, Tricellula aquatica R-X, Varicosporium elodeae $\mathrm{Y}$ and Tetracladium maxilliformis $\mathrm{Z}$. A: on Agropyron repens; B: on Agrostis tenuis; C, D, W: on Alopecurus pratensis; E-I, R-U: on Festuca pratensis; J, X: on Lolium perenne; K-O, Y: on Phleum pratense; $\mathrm{P}, \mathrm{Q}$ : on Poa pratensis; Z: on Dactylis glomerata. A: 24. XI. 1967; B: 3. XI. 1967, Hämeenlinna; C: 7. V. 1969; D: 23. XI. 1966; E: 28. III. 1968; F: 13. VI. 1968, Mikkeli; G: 17. VII. 1967; H: 23. X. 1967; I, J: 24. XI. 1967; K: 28. III. 1968; L: 12. VI. 1969, Tikkurila; M: 10. VII. 1967; N: 24. XI. 1967; O: 24. IX. 1966; P: 17. VII. 1967; Q: 24.XI. 1967; R: 30. IX.1966; S: 23.X.1967; T: 14.X. 1968, Mikkeli; U: 5. VI. 1969, Mietoinen; V: 12. VI. 1969, Tikkurila; W: 29. V. 1970; X: 15. X. 1968; Y: 30. IX. 1966; Z: 27. IX. 1966; nothing but the date = Helsinki, Viikki. 
On Agrostis stolonifera L.:

U: Helsinki, Viikki (5 specimens); InL: Inari (1 specimen).

On Agrostis tenuis Sibth.:

U: Helsinki, Viikki (12 specimens); EH: Hämeenlinna ( 5 specimens); InL: Inari ( 1 specimen).

On Alopecurus pratensis L.:

U: Helsinki, Viikki (24 specimens); ES: Mikkeli (1 specimen).

On Bromus inermis Leyss.:

U: Helsinki (3 specimens); Hyrylä (2 specimens); KP: Toholampi (1 specimen).

On Dactylis glomerata L.:

A: Jomala (2 specimens); U: Helsinki, Viikki (38 specimens), Hyrylä (1 specimen); EH: Hämeenlinna ( 6 specimens); ES: Mikkeli (6 specimens); KP: Toholampi (1 specimen).

On Deschampsia caespitosa (L.) PB:

InL: Inari (2 specimens).

On Festuca pratensis Huds.:

A: Jomala (2 specimens); U: Helsinki, Viikki (84 specimens), Tikkurila (2 specimens), Hyrylä (1 specimen); V: Mietoinen (3 specimens); $\mathrm{EH}$ Hämeenlinna (2 specimens), Pälkäne (1 specimen); St: Peipohja (8 specimens); ES: Mikkeli (8 specimens); PH: Laukaa (1 specimen); KP: Toholampi (1 specimen); PP: Ruukki (1 specimen); InL: Inari (2 specimens).

On Festuca rubra L.:

U: Helsinki, Viikki (16 specimens), Hyrylä (2 specimens); EH: Hämeenlinna (1 specimen).

On Lolium perenne L.:

U: Helsinki, Viikki (19 specimens), Hyrylä (1 specimen); St: Peipohja (2 specimens); ES: Mikkeli (1 specimen); InL: Inari (3 specimens).

On Phleum pratense L.:

U: Helsinki, Viikki (45 specimens), Tikkurila (1 specimen), EH: Hämeenlinna (3 specimens); St: Peipohja (1 specimen); ES: Mikkeli (1 specimen); KP: Toholampi (2 specimens); PP: Ruukki (2 specimens); InL: Inari (5 specimens).

\section{On Poa pratensis L.}

U: Helsinki, Viikki (19 specimens), Hyrylä (1 specimen); EH: Hämeenlinna (2 specimens); InL: Inari ( 2 specimens); in 1966-70; (HPP).

Tricellula aquatica Webster, Trans. Brit. Mycol. Soc. 42: 416-420, 1959.

This fungus has been found on decaying leaves of Alnus glutinosa Geartn., Castanea sativa Mill. and Hedera helix L., and in water in Britain (WeBster 1959). Also a few have been found in scum and foam samples from a few well-investigated waters in Småland and Upland in Sweden (NILsson 1964) as well as in soil in Kiel (Germany) and in the Netherlands (Domsar \& Gams 1970).
In the present study the fungus was found on grass samples from localities ranging from Helsinki to Lapland (at Inari). As with $V_{O}$ lucrispora graminea mentioned above spores of the fungus were found during the snow free season. Cionidia of Tricellula aquatica were found on 13 grass species and in a total of 90 samples. Spores of the fungus were found in abundance in $2 \%$ of the 3770 samples examined and also in small numbers.

The hyaline, three-celled conidia consists of a basal cell which bears at its tip two other cells (Fig. $3 \mathrm{E}$ ). The size of the total conidia (about 180 examined) averaged (9) 12.6 (15) $\mu$ long and (5) 7.5 (12) $\mu$ wide. The basal cell was (1.8) 2.3 (3.0) $\mu$ wide. The size of conidia was the same as in Webster's (1959) material. The size and form of conidia showed little variation between samples collected from different localities, grasses and at different times (Fig. 2 $\mathrm{R}-\mathrm{X}$ ). The form of spores was similar to that described by Webster (1959), PeterSEN (1962b) and Domsar and Gams (1970).

\section{Material examined}

On Agropyron repens (L.) PB:

$\mathrm{U}$ : Helsinki, Viikki (1 specimen); $\mathrm{EH}$ : Hämeenlinna (1 specimen).

On Agrostis stolonifera L.:

$\mathrm{U}$ : Helsinki, Viikki (1 specimen).

On Agrostis tenuis Sibth.:

$\mathrm{U}$ : Hyrylä (2 specimens).

On Arrhenatherum elatius (L.) M. \& K.:

$\mathrm{U}$ : Hyrylä (1 specimen).

On Alopecurus pratensis L.:

$\mathrm{U}$ : Hyrylä (2 specimens).

On Bromus inermis Leyss.:

$\mathrm{U}$ : Hyrylä (1 specimen).

On Dactylis glomerata L.:

U: Helsinki, Viikki (8 specimens), Tikkurila (1 specimen); ES: Mikkeli (2 specimens); PS: Maaninka (1 specimen); KP: Toholampi (2 specimens).

\section{On Festuca pratensis Huds.:}

U: Helsinki, Viikki (26 specimens), Tikkurila (3 specimens), Hyrylä (1 specimen); V: Mietoinen (1 specimen); EH: Pälkäne (1 specimen); St: Peipohja (2 specimens); ES: Mikkeli ( 7 specimens); KP: Toholampi (2 specimens).

On Festuca rubra L.:

U: Helsinki, Viikki (1 specimen); InL: Inari (1 specimen). 


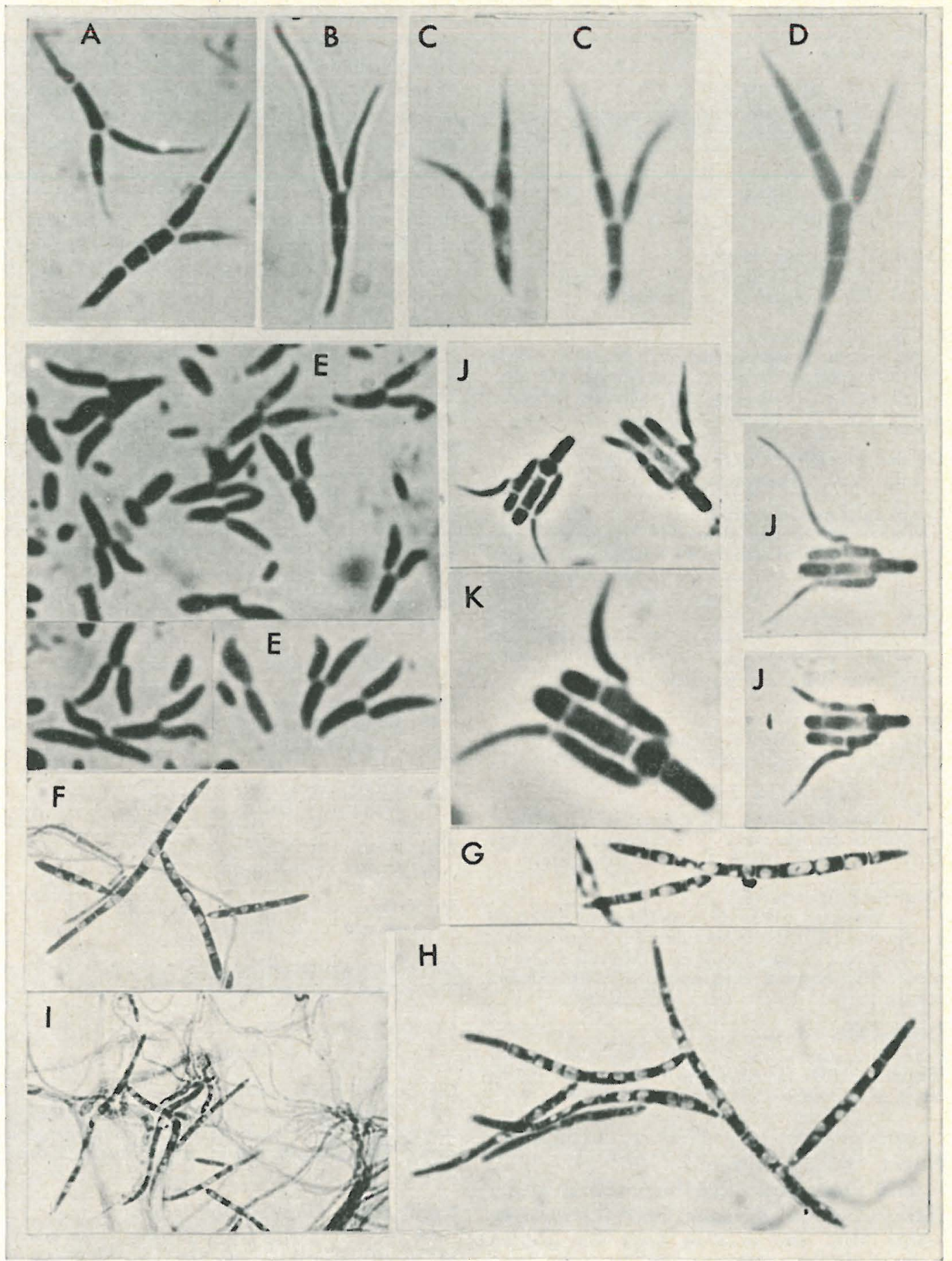

Fig. 3 Conidia of Volucrispora graminea, A-D; Tricellula aquatica, E; Varicosporium elodeae, F-I; and Tetracladium maxilliformis J, K. A, E: on Festuca pratensis, Mikkeli; A: 21. V. 1968, E: 14. X. 1968; B, C, J, K: on Dactylis glomerata; B: Hyrylä 29. V. 1970, G: Hämeenlinna 15. IV. 1968; D: on Lolium perenne, Helsinki 28. III. 1968; F-I: on Phleum pratense, Helsinki 30. IX. 1966; J, K: Helsinki 27. IX. 1966. A-E, J: x 1000, F: x 500, G, H: x 600, I: x 300, $\mathrm{K}: \times 2000$. 
On Lolium perenne L.:

U: Helsinki, Viikki (5 specimens); St: Peipohja (2 specimens).

On Phleum pratense L.:

U: Helsinki, Viikki (6 specimens), Tikkurila (1 specimen), Hyrylä (1 specimen); St: Peipohja (2 specimens).

On Poa annua L.:

EH: Jaala (1 specimen); InL: Inari (1 specimen).

On Poa pratensis L.:

U: Helsinki, Viikki (4 specimens); in 1966-70; (HPP).

Varicosporium elodeae Kegel, Ber. deutsch Bot. Ges. 24: 213--216, 1906; Ingold (1942: 394-398).

The fungus has been recorded as occurring on dead Elodea canadensis Rich. et Michx. in Germany (KeGEL 1906), on decaying older leaves in Britain (INGold 1942), on decaying leaves of Alnus glutinosa and Quercus sp. in Ireland (FENTON 1950), on submerged tissue of Drosera rotundifolia L. and on leaves of Nuphar ozeensis and on Alnus sp. in Japan (TUBAKi 1957), as well as in scum and foam samples and on submerged leaves in streams in many localities from Skåne to Lapland in Sweden (Nrlsson 1964). Bessey (1939) isolated the fungus from soil in Canada, and WAID (1954) found it on roots of beech. According to Tubaki (1957) Varicosporium elodeae is a species intermediate between aquatic and semi-aquatic. NiLsson (1964) is also of this opinion.

In the present study the fungus was found only at Viikki (Helsinki) on leaves of Phleum pratense $\mathrm{L}$. and only in 2 samples. Conidia of the fungus (Figs. $2 \mathrm{Y}, 3 \mathrm{~F}-\mathrm{I}$ ), were typically branched (cf. LINDAU 1910: 760, INGOLD 1942, Tubaki 1957). The hyaline conidia (about 60 examined) consist of a main axis (36) 60 (114) $\mu$ long, (2) 3 (4) $\mu$ wide and one to four (average 1.7) laterals (11) 40 (66) $\mu$ long, (2) 2.8 (4) $\mu$ wide. The size is close to those described by INGoLd (1942). The fungus also had hyaline mycelia (Fig. 3 I).
Material examined

On Phleum pratense L.:

U: Helsinki, Viikki 30. IX. 1966, 17. V. 1968.

Tetracladium maxilliformis (Rostrup) Ingold, Trans. Brit. Mycol. Soc. 25: 371-372, 1942; Syn. Titea maxilliformis Rostrup Bot. Tidsskr. 19: 46-47, 1894.

The fungus has been recorded as occurring on stalks of Trifolium pratense L. already attacked by Typhula trifolii Rostrup in Denmark (RostruP 1894), on decaying older leaves (INGOLD 1942), in the scum on the surface of a fresh-water ditch in England (INGOLD \& Ellis 1952), and in scum and foam samples from streams in Sweden, where it is a very rare species (NILsson 1964).

In the present study the fungus was found at Viikki (Helsinki) on one sample of leaves of Dactylis glomerata. The leaves were gathered from the ley on Sept. 27. 1966, kept in petri dishes on water-soluble agar in the refrigerator at $+5^{\circ}-+10^{\circ} \mathrm{C}$ to Jan. 12 . 1967 , then prepared on slides and examined microscopically. A fairly large number of spores were observed. According to THORNTON (1965) the optimal temperature for growth of this fungus is $+10^{\circ} \mathrm{C}$. Conidia had the typical form (Figs $2 \mathrm{Z}, 3 \mathrm{~J}, \mathrm{~K}$ ) which resembled closely those described by Rostrup (1894: 47) and INGOLD and ElLis (1952: 160).

The size of the conidia (about 30 examined) (cf. Fig. $2 \mathrm{ZZ}$ ) a: (12) 15.6 (18) $\mu$ long, (2) 2.1 (3) $\mu$ wide, b: (6) 10.1 (14) $\mu$ long, (1) 2.0 (2) $\mu$ wide, c: (10) 13.0 (20) $\mu$ long, (1) 1.4 (2) $\mu$ wide, d: (4) 8.0 (18) $\mu$ long, $1 \mu$ wide. These dimensions are close to those found by Rostrup (1894: 47, LiNDAU 1907: 545).

Material examined

On Dactylis glomerata L.:

U: Helsinki, Viikki 27. IX. 1966. 


\section{REFERENCES}

Baxter, J. W. 1960: Aquatic Hyphomycetes of Wyoming. - Mycologia 52: 654-655.

Bessey, E. A. 1939: Varicosporium elodeae Kegel, an uncommon soil fungus. - Papers Michigan Acad. Sci., Arts and Lett. 25: 15-17.

Domsch, K. H. \& Gams, W. 1970: Pilze aus Agrarböden. - 222 pp. Stuttgart.

Fenton, A. F. 1950: Aquatic Hyphomycetes of Northern Ireland. - Irish Nat. J. 10: 2223.

Haskins, R. H. 1958: Hyphomycetous fungi: Volucrispora aurantiaca n. gen., n. sp.; V. ornithomorpha (Trotter) n. comb.; and Tricellula curvatis n. sp., with the genus Tricellula emended. -- Canad. J. Microbiol. 4: $273-285$.

INGOLD, C. T. 1942: Aquatic Hyphomycetes of decaying alder leaves. - Trans. Brit. Mycol. Soc. 25: $339-417$.

- 1943: Further observation on aquatic Hyphomycetes of decaying leaves. - Trans. Brit. Mycol. Soc. 26: 104-115.

- 1944. Some new aquatic Hyphomycetes. - Trans. Brit. Mycol. Soc. 27: 35-47.

- \& Ellis, E. A. 1952: On some Hyphomycete spores, including those of Tetracladium maxilliformis, from Wheatfen. Trans. Brit. Mycol. Soc. 35: 158-161.

- MaDougall, P. J. \& Dann, V. 1968: Notes and brief articles. Volucrispora graminea sp. nov. - Trans. Brit. Mycol. Soc. 51: $325-328$.

Kegel, W. 1906: Varicosporium elodeae, ein Wasserpilz mit auffallender Konidienbildung. - Ber. Deutsch. Bot. Ges. 24: 213-216.

Lindau, G. 1907: Fungi imperfecti: Hyphomycetes. - Rabenhorst, L.: Kryptogamen-Flora von Deutschland, Oesterreich und der Schweiz. 1, 8, 852 pp. Leipzig.

- 1910: Fungi imperfecti: Hyphomycetes. Rabenhorst, L.: Kryptogamen-Flora von
Deutschland, Oesterreich und der Schweiz. 1, 9, 983 pp. Leipzig.

MäkeL $\ddot{A}, K$ K. 1972: Disease damage to the foliage of cultivated grasses in Finland. - Acta Agr. Fennica 124, 1: $1-56$.

Nilsson, S. 1962: Second note on Swedish freshwater Hyphomycetes. - Bot. Notiser 115: $73-86$.

- 1964: Freshwater Hyphomycetes. Taxonomy, morphology and ecology. - Symb. Bot. Upsal. 18, 2: 1-130.

Peterson, R. H. 1962 a: Aquatic hyphomycetes from North America. I. Aleurosporeae. Part I and key to the genera. - Mycologia 54: $117-151$.

- 1962b: Spore formation in Tricellula van Bever. and Volucrispora Haskins. - Bull. Torrey Bot. Club. 89: 287-293.

Rostrup, E. 1894: Mycologiske Meddelelser IV. - Bot. Tidskr. 19: 36-47.

Thornton, D. R. 1963: The physiology and nutrition of some aquatic hyphomycetes. - J. Gen. Microbiol. 33: 23-31.

- 1965: Amino acid analysis of fresh leaf litter and the nitrogen nutrition of some aquatic hyphomycetes. - Canad. J. Microbiol. 11: 657-662.

Tuвaki, K. 1957: Studies on the Japanese Hyphomycetes. III. Aquatic group. - Bull. Nat. Sci. Mus. Tokyo 41: 249-268.

WAID, J. S. 1954: Occurrence of aquatic Hyphomycetes upon the root surfaces of beech grown in woodland soils. - Trans. Brit. Mycol. Soc. 37: 420-421.

Webster, J. 1959: Tricellula aquatica sp. nov., an aquatic Hyphomycete. - Trans. Brit. Mycol. Soc. 42: 416-420.

Wildeman, E. de 1893: Notes mycologiques. Fascicle 2. - Ann. Soc. Belge Micr. 17: 3568. 